\author{
Almir Alihodžić \\ University of Zenica, Bosnia and Herzegovina \\ e-mail: almir.dr2Cgmail.com
}

\title{
QUANTIFICATION OF THE CREDIT RISK OF BANKS IN BOSNIA AND HERZEGOVINA REGARDING THE INDIVIDUAL MEMBERS OF THE EU
}

\section{KWANTYFIKACJA RYZYKA KREDYTOWEGO BANKÓW BOŚNI I HERCEGOWINY ODNOŚNIE DO INDYWIDUALNYCH CZŁONKÓW UE}

DOI: $10.15611 /$ nof.2017.4.01

JEL Classification: G20, G21, G29

\begin{abstract}
Summary: Credit risk is the most important risk among all other risks in the banking business, because almost over $80 \%$ of bank balance sheets relate to this segment of banking risk management. One of the biggest problems of commercial banks in Bosnia and Herzegovina are non-performing loans whose share in total loans has increased significantly since the onset of the global financial crisis. The main objective of the research is to determine which of the macroeconomic variables have the strongest impact on the increase of return on average equity and whether it is possible to reduce the credit risk of banks with adequate legislation as the main factor in the slowdown in credit expansion. The main goal will be to divide the impact of an independent variable, i.e. the share of liquid assets in total assets and whether its increase indirectly affects the return on equity and indirectly, the credit risk. The quantitative model used in this study will be the Merton model. Testing will be conducted through multiple regression analysis for the period 2008-2016 with the help of the software package STATA.
\end{abstract}

Keywords: return on average equity, regression analysis, the stability of the financial system, credit risk.

Streszczenie: Ryzyko kredytowe jest jednym z najważniejszych ryzyk sektora bankowego. Największym problemem banków komercyjnych w Bośni i Hercegowinie od czasu kryzysu finansowego jest właśnie rosnący udział zagrożonych kredytów w stosunku do kredytów ogółem. Głównym celem artykułu jest zatem ustalenie, czy jest możliwa redukcja bankowego ryzyka kredytowego przez wprowadzenie odpowiednich norm prawnych oraz wskazanie zmiennych makroekonomicznych mających największy wpływ na stopę zwrotu ze średniego kapitału. Dodatkowo dokonano podziału wpływu niezależnych zmiennych, takich jak udział płynnych aktywów w aktywach ogółem, pośredniego wpływu ich wzrostu na zmianę stopy zwrotu z kapitału oraz na ryzyko kredytowe. W badaniu posłużono się ilościowym modelem Mertona. Zastosowano analizę regresji wielorakiej dla danych z okresu 2008-2016. Do obliczeń wykorzystano oprogramowanie STATA.

Słowa kluczowe: rentowność średniego kapitału własnego, analiza regresywna, stabilność systemu finansowego, ryzyko kredytowe. 


\section{Introduction}

Credit risk is a pretext to decrease the value of certain assets of the bank, in particular loans, and may become worthless. Therefore it is not possible to collect credits, i.e. principal and interest on maturity. Often larger banks hold relatively little equity about total assets, then a relatively small percentage of total problem loans is sufficient for any bank to simply lead to failure. Among all banking risks, a significant place belongs to credit risk in the context of the source of its potential losses. For instance, the non-fulfillment of a client's obligation by the counterparty in a credit business can result in the loss of the entire claim. Also, if several key clients of a bank are unable to properly service their obligations, this can lead to large losses at a bank that can take the bank into the insolvency zone [Đukić 2011]. Banks in Bosnia and Herzegovina are joint stock companies. They are in the process of privatization to become private financial institutions. Domestic banks in 2014 are predominantly privately owned, with a share of around $94 \%$ and the rest owned by the state. In Serbia halfway into 2002 the participation of foreign capital in banks accounted for $50 \%$, and the Federation, $68 \%$ of the capital. The share of foreign ownership in 2014 was somewhat reduced in the Federation (63\%) and significantly increased in Serbia, from $50 \%$ to $88 \%$. The largest share of foreign owners is from Austria, and $63 \%$ the Federation, and $48 \%$ in Republic of Srpska. The condition, size, and structure of the banking business activities in Bosnia and Herzegovina can be seen from their aggregated balance sheet. Approximately $60 \%$ of total bank loans accounted for loans. The large volume of reserves suggests that banks still rationalize loans and do not grant loans to the extent that the available reserves allow them. The main reason is the presence of high risk in loan investments and the impossibility of finding a good debtor or the quality of the program and the company of potential borrowers. The paper is in six parts. The first part refers to introductory considerations. The second part provides a brief overview of the literature. The third part describes a brief analysis of the banking situation in the context of the selected performance. The fourth part describes the Merton risk assessment model. The fifth section refers to data and methodology of research, and the last part gives the results and recommendations for further research.

\section{Literature review}

The link between currency instability and previous credit expansion has long been noted. In the study by Caprio G., and Klingebiel D. [2003], there were identified crises or periods of instability in banking where most or all of the banking capital of the country is destroyed. The conclusion is that an extended credit boom increases the likelihood of banking crises. Increased economic growth can have a positive impact on increasing the supply of money. In this regard, increased money supply may put pressure on interest rate cuts to create the possibility of lower capital costs, 
i.e. the financial means to be cheaper, and debtors respect their financial obligations, thereby contributing to the reduction of non-performing loans [Ahmad, Ariff 2007].

One of the important macroeconomic variables of economic instability is certainly the exchange rate fluctuation. The availability of foreign currencies on the national market exerts the pressure that prices for imported inputs are greater, ultimately affecting the prices of end-products. Also, the depreciation effect of the exchange rate affects the growth in demand for loans to cover additional costs [Ngerebo 2011]. According to Anum and Abdul [2012], internal factors such as credit risk, interest income, and loans have a significant impact on the bank's profitability. Their study covered the period from 2005 to 2009 on a quarterly basis. As a technique, they applied regression analysis. It is important to note that their study did not show any external influences such as imports, exports, discount rates and inflation, which is closely related to bank profitability.

Numerous studies have dealt with the impact of diversification on banks' success. On the other hand, some studies have found that with premium diversification, that is, more diversified revenue, banks are more profitable, while others have found that a higher share of non-interest income is likely to be associated with lower or higher bank profitability. Some studies argue that the impact of income diversification on income is non-linear, i.e. diversification uses accumulation only to a certain level [Gambacorta et al. 2014]. Credit risk is the scope of the creditor's ability to become insolvent in whole or in part to fulfill their obligations. Any credit can provide such a risk even if it is approved in the technically correct form and with the appropriate warranties.

\section{A brief overview of the banking system analysis in Bosnia and Herzegovina}

The banking system of Bosnia and Herzegovina is stable in the context of capital adequacy and liquidity. The two most significant and most likely risks for banks in $\mathrm{B} \& \mathrm{H}$ are certainly the credit risk and the risk of depreciation, and consequently, the weakened credit activity of banks towards the real sector in the economy. The intensity of the decommissioning of parent banks in B\&H was the weakest in 2011 and 2012, which may be a direct correlation between the risk premium movement of European banks. Following the debt crisis, there was a fall in the credit rating of individual countries, which directly affected the increase in the risk premium, which somehow has an impact on the decommissioning of parent banks. For banks whose shares are not quoted on stock markets, which is often the case in transition countries whose capital markets are the frontier, the use of profitability coefficients is the only way to measure the success of their business. For comparisons, the bank's profitability and its components vary from bank to bank, and from one market to another market, which may be a problem when comparing. In such situations, the ability of an analyst appears in detecting variations and explaining given causes [Đukić 2011]. 
Reducing bank profitability measures helps to see the causes of earning difficulties and where management can look for solutions. Raising profitability basically depends on the careful use of financial leverage (borrowed funds in relation to capital), the careful use of the leverage from long-term assets to achieve an appropriate share of fixed income costs in order to increase operational earnings, careful control of operating costs in order to achieve higher net income, careful asset management to ensure liquidity and maximum return on any part of the asset, careful control of the exposure of the bank to the risk that losses do not overcome revenues and equity. In many economies, the G-20 has increased credit risks given the fact that there has been an increase in leverage in non-financial enterprises and households. Despite the low interest rates in many major economies, there has been an increase in public debt to cover budget deficits. The poor economic power of households and businesses in several countries has become sensitive to financial and economic conditions [IMF 2017, p. 2].

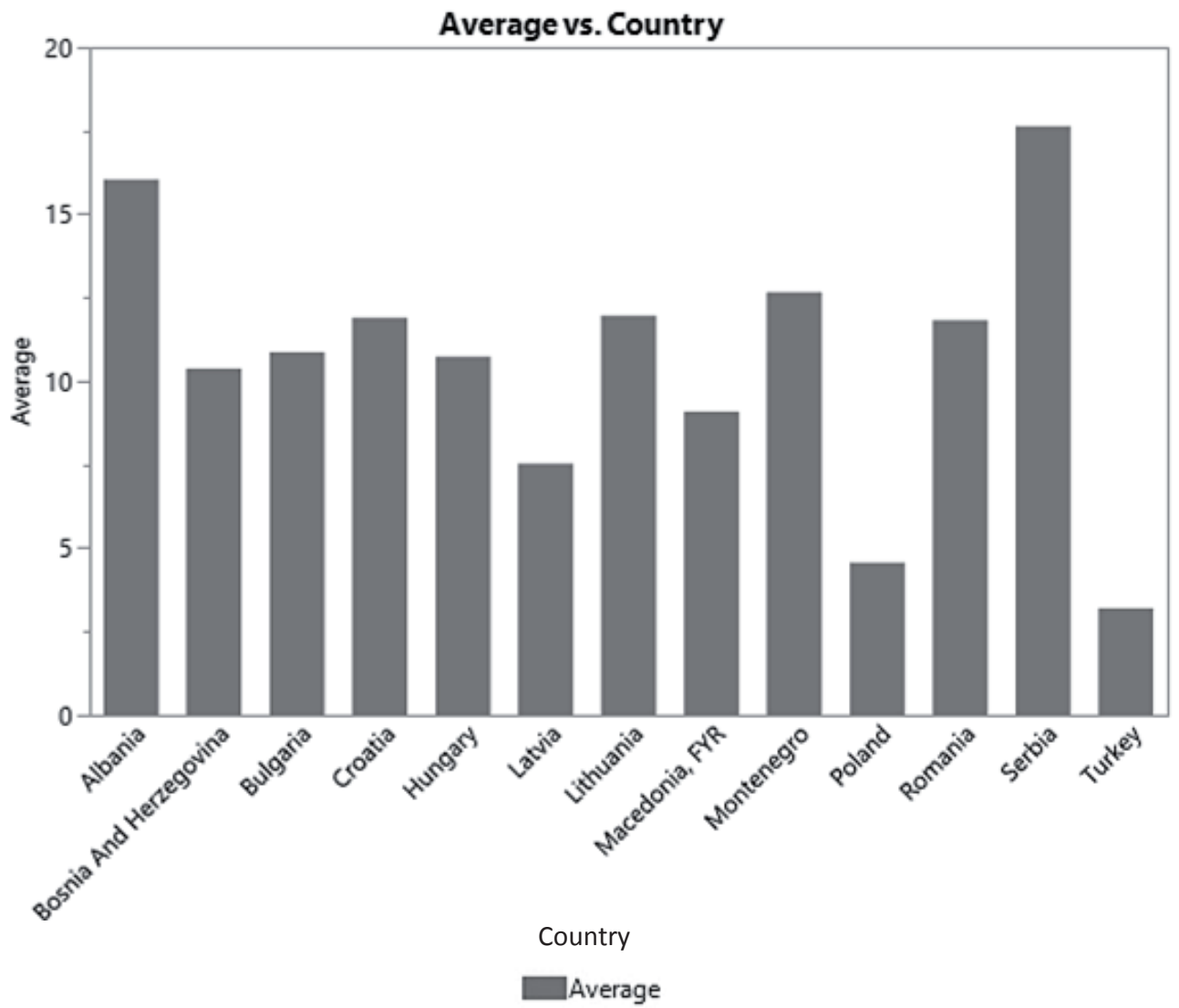

Fig. 1. Trend of moving average rate of bank nonperforming loans to total gross loans in Western Balkan countries and some EU states for the period: Q4 2008 - Q4 2016 (in \%)

Source: http://databank.worldbank.org (adjusted by the author). 
Figure 1 illustrates the tendency to move lower-quality loans in the total loan portfolio for the period: Q4 2008 - Q4 2016. The growth trend of low-quality loans started at the beginning of the global economic crisis and lasted until 2015 when there was a gradual decrease in toxic credits in total portfolio loans as a result of a mild decline in interest rates and ECB policy as a boost to demand.

The previous figure shows that the lowest average pillar of low non-performing loans in the total gross loan portfolio for the period: 2007-2016 was recorded by the following countries: Turkey (3.2\%), Poland (4.56\%), Latvia (7.53\%) and Macedonia $(9.09 \%)$. On the other hand, the largest rate of non-performing loans in the total gross loan portfolio was achieved by the following countries: Serbia $(17.63 \%)$, Albania (16.03\%), Montenegro (12.66\%), Croatia (11.89\%), and Romania (11.82\%), while other countries had a share of $10 \%$ and above $10 \%$. To reduce the level of nonperforming loans in the upcoming period, a slight downward trend should first be sought for individual and systematic solutions regarding incorporating new legislation, strict control of asset classification and strong monitoring in the selection of debtors.

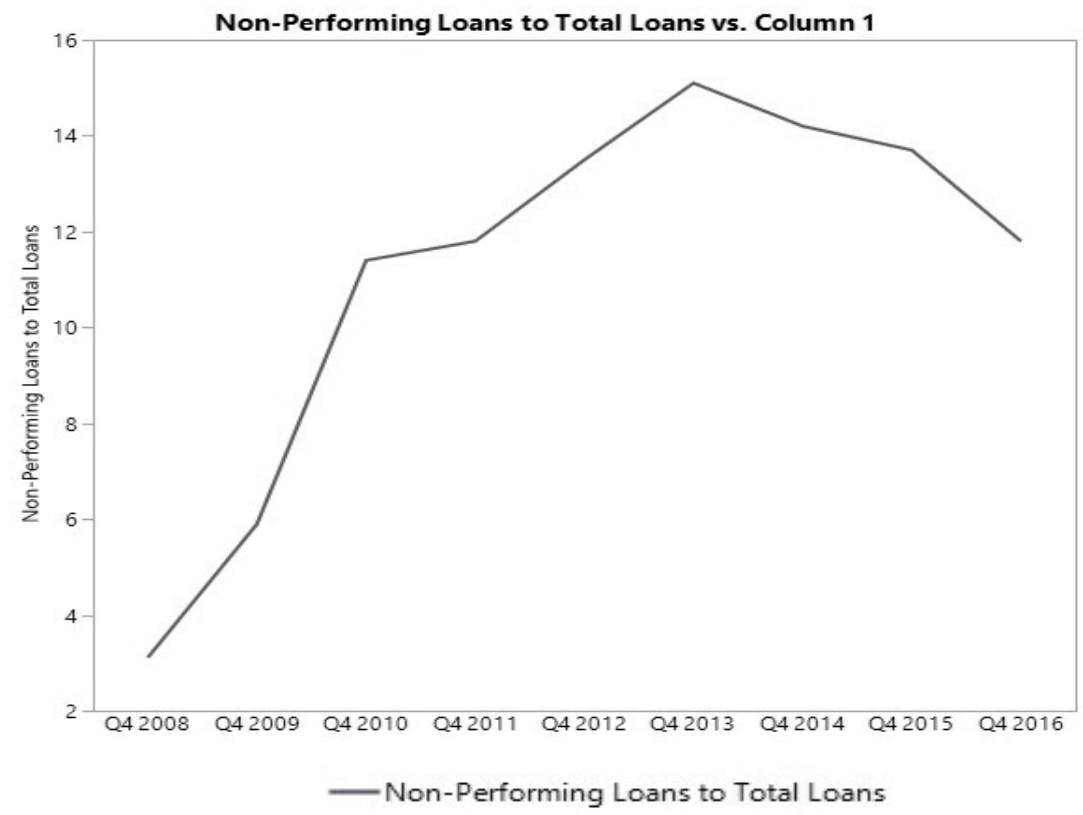

Fig. 2. Movement of non-performing loans to total loans for the period: Q1 2008 - Q4 2016 (in \%) Source: calculation by the author based on data from the Central Bank of Bosnia and Hercegovina.

The previous figure illustrates the tendency to move lower-quality loans in the total loan portfolio for the period: Q4 2008 - Q4 2016. The minimum participation of non-performing loans in the total credit portfolio was recorded in the fourth 
quarter of $2008(3.11 \%)$, while the maximum participation was realized in the fourth quarter of $2013(15.1 \%)$ and the average for the observed period of about $11.0 \%$. The reason for the steady growth of toxic credits is, above all, the bad credit policies of particular smaller banks in the context of the more stringent classification of assets and the approval of credit placements. On the other hand, most of the bad loans refer to four to five major banks that still hold a monopoly on the banking market in $\mathrm{B} \& \mathrm{H}$, where besides credit risk there is certainly a gradual risk of concentration. It should be noted that the situation of low-quality loans was also affected by the increase in the Swiss Franc credit placements, where systematic solutions are still being sought. The credit growth of banks in $\mathrm{BH}$ is mostly due to an increase in lending to the household sector, while on the other hand reduced lending to non-financial companies.

\section{The Merton credit risk assessments model}

Professor Merton presented a model that in a large number of cases explains logically the possibility of the non-fulfillment of obligations. According to this model, a debtor obligation arises when the market value of assets falls to the default value that is usually equal to the nominal debt value. Merton's model calculates the distance to default on obligations, which is based on the Black-Scholes option pricing model. Usually companies are financed from its equity and debt.

Merton's model assumes that the capital value of the company depends on the future value of the company, a couple of future obligations. In other words, the capital value of a company is a derivative of the future value of the company. Also,

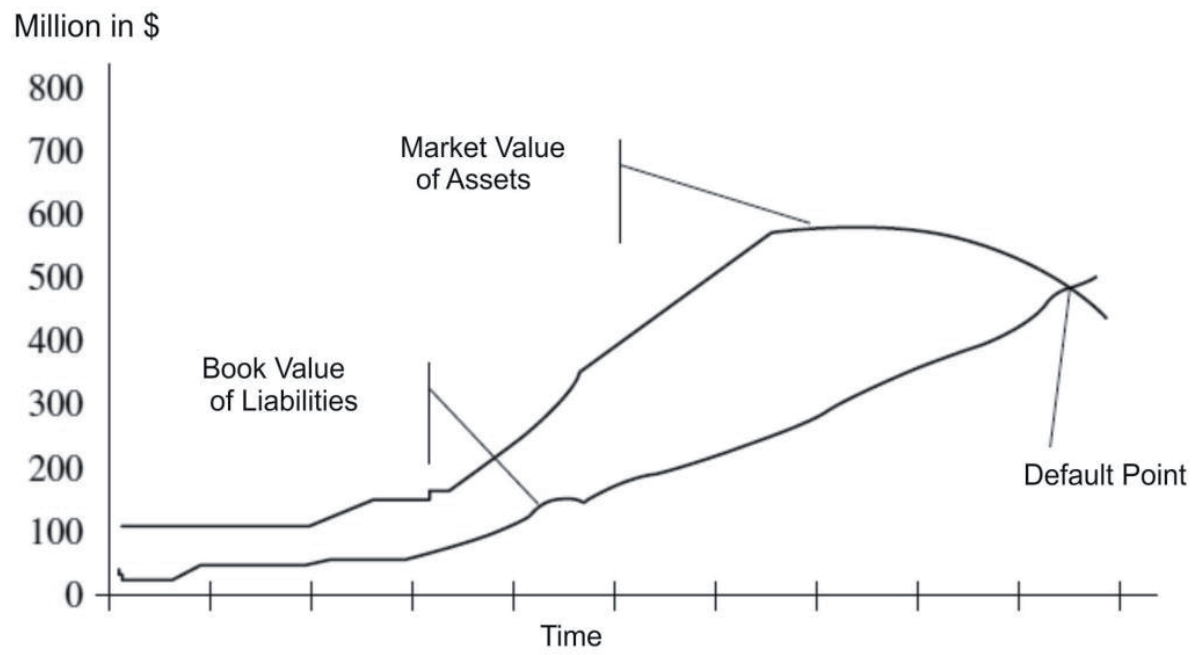

Fig. 3. Relation between market value of assets and book value of liabilities over time Source: [Ciby 2013, p. 169]. 
it is noted that Merton's model assumes that the obligations consist of individual bonds with a nominal value of $\mathrm{K}$ and maturity $\mathrm{T}$. At maturity, the debt will be paid in full if the total asset value is greater than the debt value. In such circumstances, stockholders can enjoy the rest of the asset value.

However, if the value of the asset is less than the debt, then it reflects nonfulfillment, and in such cases, the creditor may file a request for the termination of business to obtain liquidation value and where the shareholders do not receive anything in this case. Consequently, Merton's model confirms that the shareholder's contribution to pricing the options is useful for identifying the probability of a firm ending with the positive TNW when repaying outstanding liabilities.

In many cases, the change is gradual over time as shown in the free curve. Thus, the greater the gap between assets and liabilities the lower the PD. Also, the migration of credit risk can be incorporated into the model. If the distance becomes shorter, it means the risk of migration. According to the Merton model, the value of share capital in a company is calculated as follows:

$$
V_{E}=V_{A} N\left(d_{1}\right)-e^{-r(T-t)} D N\left(d_{2}\right),
$$

where: $V_{E}$-value of equity; $V_{A}$ - value of the firm; $D$ - debt of the firm; $N\left(d_{1}\right)$ and $N\left(d_{2}\right)$ - normal distribution variable.

\section{Methodology and data}

\subsection{Methodology}

A simple linear regression model expresses a relationship between two parameters as follows:

$$
Y_{i}=\alpha+\beta X_{i}+\varepsilon_{i} \quad i=1,2, \ldots \ldots n,
$$

where: $Y$ - dependent variable; $\alpha i$ - unknown parameters that need an estimate, and $i^{-}$stochastic variable (error distances).

To analyze the determinants of the return on equity capital in the banking sector of Bosnia and Herzegovina, the linear regression model stated below will be estimated:

$$
Y_{t}=\beta_{0}+\beta_{1} X_{1 t}+\beta_{2} X_{2 t}+U_{t}
$$

where: $t-$ refers to quarter; $Y_{t}$-is a dependent variable in a particular period (quarter) $t$, the $\beta_{0}$ represents the intercept; $X$ represents the selected determinants of the money supply; $\beta_{1}$ and $\beta_{2}$ are coefficients, and $U_{t}$ represents the error term.

The equation which is the adjusted regression model in this paper can be expressed as follows:

$$
\begin{aligned}
R O E= & \beta_{0}+\beta_{1} N P L T L_{t}+\beta_{2} N_{I E T I}+\beta_{3} L N F P C_{t}+\beta_{4} L H S_{t} \\
& +\beta_{5} \text { LATS }_{t}+\beta_{6} \text { PBSGDP }_{t}+\text { EM }_{t}+\text { CAR }_{t}+U_{t^{*}}
\end{aligned}
$$


The representation of the model will examine the calculation of the coefficient of correlation $(r)$, the coefficient of determination $R^{2}$ and the adjusted coefficient of determination $\left(R^{2}\right)$. There is also an analysis of variance (ANOVA), which will test the significance of the observed variables in the model, where the null hypothesis is the reason why the independent variables do not significantly affect the dependent:

$$
\begin{aligned}
& H_{0} \ldots \beta_{1}=0, \\
& H_{1} \ldots \beta_{1} \neq 0 .
\end{aligned}
$$

\subsection{Data}

In this paper, the return on equity of banks (ROE) in $\mathrm{B} \& \mathrm{H}$ will be used as dependent variables, while the independent variables will use the following: non-performing loans to total loans (NPLTL), non-interest expenses to total expense (NIETE), loan to non-financial public company (LNFPC), loan to household sector (LHS), liquid assets by total assets (LATS), participation of banking assets in the gross domestic products (PBSGDP), equity multiplier (EM) and capital adequacy ratio (CAR). The research period covers the period from the first quarter of 2008 to the fourth quarter of 2016. The analysis will be made using quarterly data, as the number of annual data is insufficient for econometric evaluation. The table below gives a short description of the independent variables in the model.

\begin{tabular}{|c|c|c|c|c|}
\hline Independent Variables & Abbreviation & Description & Formula & $\begin{array}{l}\text { Expected } \\
\text { relationship } \\
\text { with }\end{array}$ \\
\hline $\begin{array}{l}\text { Non-performing loans to } \\
\text { total loans } \\
\text { Non-interest expenses to } \\
\text { total income } \\
\text { Loans to non-financial } \\
\text { public company }\end{array}$ & $\begin{array}{l}\text { NPLTL } \\
\text { NIETI } \\
\text { LNFPC }\end{array}$ & $\begin{array}{l}\text { Non-performing loans } \\
\text { to total loans } \\
\text { Non-interest expenses to total } \\
\text { income } \\
\text { Loans to non-financial public } \\
\text { company }\end{array}$ & $\begin{array}{l}\text { NIETI } \\
- \\
\end{array}$ & $\begin{array}{l}\text { Negative }(-) \\
\text { (Negative }(-) \\
\text { Positive }(+)\end{array}$ \\
\hline Loans to household sector & LHS & Loans to household sector & - & Positive $(+)$ \\
\hline Liquid assets by total assets & LATS & Liquid assets by total assets & - & Negative (-) \\
\hline $\begin{array}{l}\text { Participation of banking } \\
\text { assets in the }\end{array}$ & PBSGDP & $\begin{array}{l}\text { Participation of banking assets } \\
\text { in the gross domestic products }\end{array}$ & - & Positive $(+)$ \\
\hline $\begin{array}{l}\text { gross domestic products } \\
\text { Equity Multiplier }\end{array}$ & EM & $\begin{array}{l}\text { The equity multiplier is a ratio } \\
\text { used to analyse a } \\
\text { banks, debt and equity financing } \\
\text { strategy }\end{array}$ & $\begin{array}{l}\text { EM=Total } \\
\text { Assets/Total } \\
\text { Stockholder's } \\
\text { Equity }\end{array}$ & Positive $(+)$ \\
\hline Capital Adequacy Ratio & CAR & $\begin{array}{l}\text { Capital Adequacy Ratio is used } \\
\text { to protect } \\
\text { depositors and promote the } \\
\text { stability and } \\
\text { efficiency of financial systems }\end{array}$ & $\begin{array}{l}\text { CAR=Tier One } \\
\text { Capital+Tier Two } \\
\text { Capital/Risk } \\
\text { Weighted Assets }\end{array}$ & Negative - \\
\hline
\end{tabular}

Table 1. Summary of variables description

Source: organized by the author. 


\subsection{Results}

The table below illustrates the descriptive statistics of selected independent and dependent variables in the model.

Table 2. Descriptive statistics of dependent and independent variables for the period: Q1 2008 - Q4 20

\begin{tabular}{|l|c|c|c|c|c|}
\hline \multicolumn{1}{|c|}{ Variables } & Obs & \multicolumn{1}{c|}{ Mean } & Std. Dev. & Min & Max \\
\hline ROE & 35 & 4.461 & 4.121 & -5.5 & 11.1 \\
\hline NPLTL & 35 & 10.814 & 4.246 & 3.0 & 16.1 \\
\hline NIETI & 35 & 87.538 & 10.386 & 70.6 & 110.9 \\
\hline LNFPC & 35 & 357.11 & 71.415 & 251.63 & 450.73 \\
\hline LHS & 35 & 6922.69 & 587.469 & 5993.12 & 8076.28 \\
\hline LATS & 35 & 27.281 & 2.642 & 24.12 & 34.88 \\
\hline PBSGDP & 35 & 0.338 & 0.018 & 0.314 & 0.374 \\
\hline EM & 35 & 80.951 & 9.539 & 66.159 & 100.42 \\
\hline CAR & 35 & 16.288 & 0.744 & 14.9 & 17.8 \\
\hline
\end{tabular}

Source: calculated by the author (STATA 13.0).

Regarding the variability of the selected variables measured through the standard deviation, it is noted that the highest value of standard deviations was realized by household sector loans (587\%) as well as loans directed at non-financial public enterprises $(71.41 \%)$. During the period from the last quarter of 2008 to the fourth quarter of 2016, the total increase in household sector loans was about $34 \%$. The largest share belongs to the consumer and classic loans. In the first six months of 2015 , the overall growth rate of loans to the household sector ranged from 5.5\% to $5.8 \%$, with a slight decline in lending by the population of $4.23 \%$ in the first quarter of 2016. This is all a result of stricter access to credit granted by banks, and on the other hand, the available income and over-indebtedness of the population sector are weakened. Credit growth of non-financial public enterprises was the largest in 2004, almost 1.1 billion BAM. After 2004, there was a sharp fall in lending to the nonfinancial sector via bank loans. Since 2004, non-financial public companies have been financed from their budget sources, some from foreign sources of funding and projects. Thus, due to the weakened demand of the non-financial public sector, banks have made the transformation of lending to the government sector after the global economic crisis to preserve the net lending margins.

From the previous correlation matrix, it is clear that the strongest positive link with the return on equity was realized with the following variables: loans to the household sector (0.33), equity multiplier (0.28) and participation of banking assets in the gross domestic products $(0.26)$. Certainly, credit expansion has a positive impact on the growth of return on average capital. In the period 2011-2012, banks in BH had an average return on capital growth of about $5.5 \%$, in 2013 they fell sharply by about $(-0.5)$ in 2013 as the result of bad credit policies and losses of individual 
Table 3. Partial and semipartial correlation between independent and dependent variables for the period: Q1 2008 - Q4 2016

\begin{tabular}{|l|c|c|c|c|c|}
\hline \multicolumn{1}{|c|}{ Variables } & Partial Corr. & $\begin{array}{c}\text { Semipartial } \\
\text { Corr. }\end{array}$ & $\begin{array}{c}\text { Partial Cor. } \\
\wedge 2\end{array}$ & $\begin{array}{c}\text { Semipartial } \\
\text { Corr. }{ }^{2} 2\end{array}$ & $\begin{array}{c}\text { Significance } \\
\text { Value }\end{array}$ \\
\hline NPLTL & 0.127 & 0.024 & 0.016 & 0.001 & 0.511 \\
\hline NIETI & -0.936 & -0.508 & 0.876 & 0.258 & 0.000 \\
\hline LNFPC & 0.182 & 0.035 & 0.033 & 0.001 & 0.345 \\
\hline LHS & 0.330 & 0.066 & 0.109 & 0.004 & 0.080 \\
\hline LATS & -0.294 & -0.058 & 0.086 & 0.003 & 0.121 \\
\hline PBSGDP & 0.256 & 0.051 & 0.067 & 0.003 & 0.173 \\
\hline EM & 0.280 & 0.055 & 0.078 & 0.003 & 0.141 \\
\hline CAR & -0.282 & -0.056 & 0.079 & 0.003 & 0.139 \\
\hline
\end{tabular}

Source: calculated by the author (STATA 13.0).

banks. It is noteworthy that credit growth rates in the household sector are higher than the non-financial public sector. Thus, for example, the rate of credit by the end of 2015 by non-financial public enterprises was less than $2 \%$ [The Central Bank of Bosnia and Herzegovina, Financial Stability Report, 2015, p. 46]. On the other hand, the strongest negative correlation was recorded between return on equity and the following independent variables: no-interest expense to total income (0.94), then liquid assets by total assets $(-0.29)$ and capital adequacy ratio $(-0.28)$. Most of the non-interest expenses relate to the operating costs of the employees, which, with the increase of these, directly leads to a decrease in earnings on the share capital, i.e. there is an inverse causality between them. The largest share of liquid assets in total assets was recorded in 2007, with about $41 \%$, at the end of 2013 there was a dramatic decrease in liquid assets in total assets of only $19 \%$. This is primarily the result of rationalization with credit approval due to the high credit risk present and the inability to find good debts.

Therefore, with the increased share of liquid assets in total assets as recorded in banks before the crisis and several years after, it can be concluded that banks have refrained from approving new loans of uncertainty, which in turn led to increased liquidity, but on the other hand reducing return on equity. As stated in the summary of the paper, toxic credits before the crisis period were at an extremely low level, where linear growth followed several years after the crisis. Table 4 illustrates the ANOVA analysis of the dependent and independent variables in the model.

Based on the results of regression analysis, the coefficient of determination is $\mathrm{R} 2=96 \%$, while the adjusted coefficient of determination is $\mathrm{R} 2=0.95$, which means that there is a $95 \%$ change in the independent variables to the dependent relation. Testing the null hypothesis of significance obtained statistically significant data indicating that there is the significant influence of certain independent variables at a significance level of $\alpha=5 \%$ and that the empirical F-ratio is (89.19). As for this 
Table 4. The basic model of regression analysis between the independent and dependent variable for the period from Q1 $2008-$ Q4 2016

\begin{tabular}{|l|r|r|r|}
\hline \multicolumn{1}{|c|}{ Source } & \multicolumn{1}{c|}{ SS } & df & \multicolumn{1}{c|}{ MS } \\
\hline Model & 572.732 & 8 & 71.59 \\
\hline Residual & 21.673 & 27 & 0.802 \\
\hline Total & $\mathbf{5 9 4 . 4 0 5}$ & $\mathbf{3 5}$ & $\mathbf{1 6 . 9 8 3}$ \\
\hline
\end{tabular}

\begin{tabular}{|l|c|}
\hline Number of observation & 35 \\
\hline F $(8,27)$ & 89.19 \\
\hline Prob $>$ F & 0.000 \\
\hline R-squared & 0.9635 \\
\hline Adj R-squared & 0.9527 \\
\hline Root MSE & 0.89594 \\
\hline
\end{tabular}

\begin{tabular}{|l|c|c|c|c|c|r|}
\hline Variables & Coef. & Std. Err. & $\mathrm{t}$ & $\mathrm{P}>[\mathrm{t}]$ & \multicolumn{2}{|c|}{$[95 \%$ Conf. Interval] } \\
\hline NPLTL & 0.0974 & 0.1462 & 0.67 & 0.511 & -0.2027 & 0.3974 \\
\hline NIETI & -0.3633 & 0.0262 & -13.83 & 0.000 & -0.4171 & -0.3094 \\
\hline LNFPC & 0.0093 & 0.0096 & -0.96 & 0.346 & -0.0292 & 0.0105 \\
\hline LHS & 0.0008 & 0.0004 & 1.82 & 0.080 & -0.0001 & 0.0017 \\
\hline LATS & -1.5374 & 0.9613 & -1.60 & 0.121 & -3.5097 & 0.4349 \\
\hline PBSGDP & 108.624 & 77.661 & 1.40 & 0.173 & -50.723 & 267.971 \\
\hline EM & 0.5074 & 0.3347 & 1.52 & 0.141 & -0.1793 & 1.1942 \\
\hline CAR & -0.5140 & 0.3370 & 1.53 & 0.139 & -0.1775 & 1.2056 \\
\hline cons & -11.472 & 29.931 & -0.38 & 0.705 & -72.886 & 49.941 \\
\hline
\end{tabular}

Source: calculated by the author (STATA 13.0).

study, the value of the empirical F-ratio (89.19) is greater than the theoretical value of F-ratio (2.31) for the 8-degree of freedom in the numerator and 27 in the denominator, therefore we came to the conclusion to reject the null hypothesis that the independent variables have a significant impact on the dependent variable. From the previous table it can be seen that the strongest positive correlation was recorded between return on equity and participation of banking assets in the gross domestic products (108.62\%). This result has its logical explanation, as with the increase in economic activity, banking assets are increasingly primarily regarding loans, which has a positive impact on the return on equity. The inverse connection between return on equity and equity multiplier is a logical sequence, as usually big banks have a larger capital multiplier, i.e. they retain less capital to increase profits. Given that capital must absorb potential losses from the banking business, the larger the multiplier, the greater the exposure of the bank failures. But on the other hand, with a larger multiplier, a larger return is made to shareholders.

\section{Conclusion}

In order for the bank to successfully manage risk, it is necessary to continually plan and maintain an acceptable relationship between the risk assumed and the actual level of accrual, and to control and minimize all risks related to asset quality, 
concentration, billing and to provide collateral, and the risks related to maturity and currencies in certain parts of assets and liabilities. Credit risk poses a potential and real threat to bank operations in B\&H. No special reduction can be expected in the upcoming period until the recovery of economic activity in the country in the context of the further growth of the gross domestic product. Poor credit expansion continues to pose a threat to the domestic banking sector. Credit growth is largely determined by the credit activity of the household sector. In addition to credit risk, the risk of deleveraging represents the secondary risk of the banking system as a result of impaired credit activity. In this study, the zero hypothesis was discarded because it was not shown that the selected independent variables did not affect the selected dependent variables. The results of the analysis showed that the strongest correlation was recorded between the return on equity and the participation of banking assets in the gross domestic products as well as between the equity multiplier. In the context of negative causality, the strongest negative correlation is realized between return on equity and liquid assets by total assets, and between the capital adequacy ratio and non-interest expenses to total income. Over the next few years, it will be a great challenge to improve the performance of domestic banks due to increased competitiveness, concentration, poor economic growth, saturation of economy and population loans, i.e. indebtedness, slow growth in demand for loans, slow employment growth, etc. To answer these problems and to take into account the turbulent economic environment is a very important forecast, and planning bank performance, as well as all the elements and instruments relevant to the performance, can be realized.

\section{Bibliography}

Ahmad N.H., Ariff M., 2007, Multi-country study of bank credit risk determinants, The International Journal of Banking and Finance, 5(1), pp. 135-152.

Anum J.B., Abdul Q., 2012, Internal and external determinates of profitability of banks: Evidence from Pakistan, Interdisciplinary Journal of Contemporary Research in Business, 3(9), pp. 1037-1058.

Caprio G., Klingebiel D., 2003, Episodes of Systemic and Borderline Financial Crises, [in:] Klingebiel D. (ed.), The World Bank, Washington DC.

Ciby J., 2013, Advanced Credit Risk Analysis and Management, John Wiley\& Sons, Ltd.

Đukić Đ., 2011, Risk and Capital Management in Banks, Center for Publishing of the Faculty of Economics in Belgrade, Belgrade.

Đukić Đ., 2012, Banking and Crisis - International and Domestic Aspects, Center for Publishing Activities of the Faculty of Economics in Belgrade, Belgrade.

Frederic S.M., 2013, The Economics of Money, Banking, And Financial Markets, Pearson Education.

Gambacorta L., Scatigna M., Yang J., 2014, Diversification and bank profitability: A nonlinear approach, Applied Economics Letters, vol. 21, pp. 438-441.

Howells P., Bain K., 2005, The Economics of Money, Banking and Finance, FT Prentice Hall, England. http://databank.worldbank.org/data/reports.aspx?source=2\&series=FB.AST.NPER.ZS\&country.

http://econ.worldbank.org/view.php?id=23456.

http://www.investopedia.com/terms/c/capitaladequacyratio.asp. 
International Monetary Fund, 2017, Global Financial Stability Report - Is Growth at Risk? October, http://www.imf.org/en/publications/gfsr/issues/2017/09/27/global-financial-stability-report-october-2017 (accessed on January 11, 2018).

Lukić R., 2010, Revision in Banks, Center for Publishing Activities of the Faculty of Economics in Belgrade, Belgrade.

Ngerebo T.A., 2011, The impact of foreign exchange fluctuation on the intermediation of banks in Nigeria (1970-2004), African Journal of Business Management, 6(11), pp. 3872-3879.

Plakalović N., Alihodžić A., 2015, Money, Banks and Financial Markets, Faculty of Economics University of Banja Luka.

The Central Bank of Bosnia and Herzegovina, 2015, Annual Report, http://www.cbbih.ba.

The Central Bank of Bosnia and Herzegovina, 2015, Financial Stability Report, http://www.cbbih.ba. 